\title{
Strategi Komunikasi dalam Membangun Awareness Wisata Halal di Kota Bandung
}

\author{
Soraya Ratna Pratiwi ${ }^{1}$, Susanne Dida ${ }^{2}$, Nuryah Asri Sjafirah ${ }^{3}$ \\ ${ }^{1}$ Institut Teknologi dan Bisnis Kalbis \\ ${ }^{2,3}$ Universitas Padjadjaran
}

\begin{abstract}
ABSTRAK
Wisata halal saat ini menjadi fenomena baru dalam dunia pariwisata dan mulai dikembangkan di beberapa negara. Wisata halal merupakan wisata yang pada pelaksanaannya mengacu pada syariat Islam, baik akomodasi, atraksi, dan objek wisata itu sendiri. Di Kota Bandung, wisata halal belum banyak dikenal dan masih pada tahap persiapan pengembangan, sehingga perhatian dan kepedulian terhadap wisata halal di kota ini masih belum terbangun. Dalam menangani masalah tersebut, diperlukan sebuah strategi komunikasi untuk membangun perhatian dan kepedulian di kalangan para pemangku kepentingan termasuk masyarakat. Tujuan penelitian ini adalah untuk merumuskan strategi komunikasi dalam rangka membangun perhatian dan kepedulian para pemangku kepentingan termasuk masyarakat terhadap pengembangan wisata halal di Kota Bandung. Penelitian ini menggunakan teori Konstruksi Sosial Atas Realita yang dicetuskan oleh Burger dan Luckmann. Penelitian ini juga menggunakan metode kualitatif melalui pendekatan studi kasus instrumental tunggal. Teknik pengumpulan data dilakukan melalui wawancara dan observasi. Hasil penelitian menunjukkan bahwa wisata halal di Kota Bandung dikembangkan melalui dukungan dari berbagai lintas lembaga, yang disebut strategi penta helix. Strategi komunikasi yang dilakukan oleh Dinas Pariwisata dan Kebudayaan Provinsi Jawa Barat dalam mempersiapkan Kota Bandung sebagai destinasi wisata halal dengan melakukan sosialisasi untuk menumbuhkan kesadaran (awareness) kepada SKPD terkait. Selain Dinas Pariwisata dan Kebudayaan Provinsi Jawa Barat, beberapa lembaga lain seperti Enhaii Halal Tourism Center (EHTC) dan Salman Halal Center melakukan awareness building kepada para pemangku kepentingan dan juga masyarakat. Diperlukan strategi komunikasi yang lebih kompleks untuk mengomunikasikan wisata halal kepada stakeholders dan juga masyarakat.
\end{abstract}

Kata-kata Kunci: Awareness; komunikasi pariwisata; strategi komunikasi; wisata halal; wisata kota bandung

\section{Communication Strategy in Building Awareness of Halal Tourism in Bandung City}

\begin{abstract}
Halal tourism is a new phenomenon in the world of tourism. Halal tourism is a tourism concept which implements Islamic Shari'ah laws, in terms of accommodation, attractions, and tourist attraction. The halal tourism has not been widely known and still in the preparation stage of development in Bandung. Therefore, communities' awareness of the halal tourism has not been built yet. In dealing with the problem, a communication strategy is needed to build concerns and awareness among stakeholders including the communities. The purpose of this research is to map the communication strategy in order to build the concerns and awareness of stakeholders and the communities towards the development of halal tourism in Bandung. This study uses Social Construction of Reality theory. This study also uses qualitative methods through a single instrumental case study approach. Data collection technique is done by means of interview and observation. So far the parties that play a role in developing halal tourism in Bandung is the Department of Tourism and Culture of West Java Province, STP Bandung, Salman Halal Center, and MUI Bandung. The targets of the communications are the Government in Bandung City as well as in the West Java Province, industry players, and the communities. Awareness raising of halal tourism needs to be done through education and other awareness raising programs to maximize market potential and resources owned. It takes a strong commitment from the Government and the private sector to make Bandung as a halal tourist destination.
\end{abstract}

Keywords: Awareness; bandung tourism; communication strategy; halal tourism; tourism communication

Korespondensi: Soraya Ratna Pratiwi, M.I.Kom. Program Studi Ilmu Komunikasi, Fakultas Industri Kreatif, Institut Teknologi dan Bisnis Kalbis. J1. Pulomas Selatan Kav.22, Kayu Putih, Kota Jakarta Timur, Daerah Khusus Ibukota Jakarta 13210.Email: soraya.pratiwi@kalbis.ac.id 


\section{PENDAHULUAN}

Kegiatan wisata sudah menjadi bagian esensial dalam kehidupan sehari-hari. Wisata biasa dilakukan sebagai bentuk pemuasan diri atau sekedar menghabiskan waktu luang. Salah satu jenis wisata yang sedang berkembang saat ini adalah wisata halal. Fenomena meningkatnya pertumbuhan wisatawan muslim memberikan segmentasi baru bagi sektor pariwisata dan mempengaruhi industri pariwisata secara global. Berdasarkan laporan Standing Committee for Economic and Commercial Cooperation of the Organization of Islamic Cooperation (COMCEC) pada tahun 2016, kedatangan pengunjung Muslim di negara OIC (The Organisation of Islamic Cooperation) dan non-OIC diperkirakan mencapai 116 juta pada tahun 2014 dan diproyeksikan akan tumbuh menjadi 178 juta pada tahun 2020 .

Pariwisata adalah perjalanan atau bepergian secara rekreasi atau untuk tujuan penelitian dan bukan untuk kepentingan mendapatkan uang, bekerja, atau menetap baru. Ajaran Islam mengatur apabila melakukan wisata agar sesuai dengan syariah yang menjunjung tinggi perlindungan agama, kehidupan, pikiran, dan lainnya (Battour, et al, 2010). Wisata halal merupakan bagian dari industri pariwisata yang ditujukan untuk wisatawan muslim. Dapat didefinisikan bahwa wisata halal adalah objek atau aksi wisata yang memenuhi ketentuan syariat Islam untuk digunakan atau dilibatkan dalam industri pariwisata (Battour \& Ismail, 2015). Berdasarkan definisi tersebut, wisata halal mempertimbangkan hukum Islam dalam menentukan produk dan layanan wisata, seperti hotel, makanan, atraksi, dan perjalanan wisata itu sendiri. Wisata jenis ini tidak selalu bertujuan untuk perjalanan religi dan lokasi kegiatan wisata tidak terbatas pada negara atau wilayah muslim saja, namun juga berlaku di negara atau wilayah yang penduduknya mayoritas nonmuslim.

Tujuan dari pembangunan wisata halal adalah untuk memenuhi kebutuhan pasar wisatawan muslim akan tersedianya akomodasi wisata yang sesuai dengan syariat Islam. Dalam laporan COMCEC (2016) disebutkan beberapa kriteria kebutuhan wisatawan muslim saat melakukan wisata yang disebut dengan faith based needs. Kebutuhan tersebut mencakup tersedianya: (1) makanan halal, (2) fasilitas beribadah yang layak, (3) pelayanan saat bulan Ramadhan, (4) toilet yang menyediakan air (water friendly washrooms), dan (5) fasilitas rekreasi yang memberikan privasi, dan (6) tidak ada aktivitas non halal.

Hal pendukung lainnya dalam mewujudkan wisata halal ini adalah sertifikasi halal. Wisatawan muslim bersikap sangat kritis perihal makanan. Wisatawan muslim cenderung memilih dan mempercayai produk dan pelayanan yang berlogo halal. Survey Muslim Travel Shopping Index (MTSI) 2015 menunjukkan bahwa lebih dari $80 \%$ responden memilih destinasi wisata yang menyediakan makanan halal (Pratiwi, et al, 2017). Dengan demikian, sertfikasi halal sangat dibutuhkan dan penting untuk menjamin dan meyakinkan wisatawan bahwa makanan yang dipilihnya adalah makanan halal.

Fenomena meningkatnya wisatawan muslim turut mempengaruhi industri pariwisata secara global. Kini, industri pariwisata negaranegara di Asia, Eropa, dan Timur Tengah sedang gencar mengusung wisata halal sebagai salah satu jenis wisata yang ditawarkan untuk menarik lebih banyak wisatawan ke negaranya. Oleh karena itu, wisata halal kini tengah dikembangkan di beberapa negara, bahkan memiliki konferensi berskala dunia yang dinamakan World Halal Tourism Summit (WHTS). World Halal Tourism Summit (WHTS) merupakan salah satu event pariwisata internasional untuk wisata halal. WHTS akan menawarkan peserta pameran dan pengunjung bermacam peluang bisnis pariwisata halal. Pada tahun 2015, kegiatan ini diikuti oleh 202 eksibitor, di antaranya perwakilan dari Indonesia, Bosnia, Kenya, UAE, Thailand, Sri Lanka, Maroko, Yordania, Malaysia, Turki, Oman, Palestina, Kroasia, Iran, Mesir, Tanzania, UK, Kanada, Maladewa dan Libanon (Yuanita, 2016). Negara yang mengikuti event pariwisata ini memiliki latar belakang demografi yang berbeda-beda. Dapat dilihat, bahwa negara yang mayoritas penduduknya bukan beragama Islam, namun mereka sangat terbuka dengan konsep wisata halal ini. Wisata halal bukan hanya terbuka bagi umat muslim saja, namun juga terbuka bagi semua orang yang tertarik untuk menikmati fasilitas yang tersedia dalam wisata halal.

Menurut COMCEC (2016) saat ini, negara yang memimpin dengan keunggulan wisata 
halalnya adalah Malaysia. Malaysia memiliki program sertifikasi halal yang ketat yang dapat membantu wisatawan mengidentifikasi outlet halal dengan melihat logo sertifikasi halal yang dipajang pada outlet tersebut. Pada tahun 2015, Malaysia menduduki peringkat pertama destinasi muslim berdasarkan hasil Global Muslim Travel Index (GMTI). Kunci dan keunikan kekuatan yang dimiliki Malaysia adalah identifikasi pasar Muslim sebagai pasar prioritas dan berpotensial semenjak 2009. Sehingga, Malaysia sudah memiliki fasilitas faith based needs yang sangat memadai dan mudah ditemukan.

Di Indonesia, wisata halal dikembangkan menjadi program nasional oleh Kementerian Pariwisata. Dalam rangka melakukan percepatan wisata halal, Kementerian Pariwisata menetapkan 15 provinsi yang menjadi fokus pengembangan destinasi wisatawan muslim unggulan. Jawa Barat menjadi salah satu provinsi unggulan tersebut dengan memiliki jumlah penduduk muslim terbesar di Indonesia.

Pengelolaan wisata tidak dapat dilakukan oleh satu pihak saja. Menurut Weaver dan Opperman (dalam Pitana \& Diarta, 2009) pariwisata merupakan fenomena dan hubungan yang timbul dariinteraksi di kalangan wisatawan, pemasok bisnis, pemerintah penyelenggara, masyarakat setempat, pemerintah asal, perguruan tinggi, komunitas perguruan tinggi, dan organisasi non-pemerintah, dalam proses menarik, mengangkut, hosting, dan mengelola wisatawan dan pengunjung lainnya. Pada pelaksanaannya, Kementerian Pariwisata dibantu dan didukung oleh tingkat Dinas Kebudayaan dan Pariwisata tingkat provinsi dan kota / kabupaten setempat.

Percepatan pengembangan wisata halal di Jawa Barat dimulai sejak tahun 2016. Dari 26 kota/kabupaten yang ada di Jawa Barat, Kota Bandung dianggap paling berpotensi dan mampu merepresentasikan wisata halal. Kota ini dinilai memiliki kelengkapan infrastruktur dan program wisata yang dapat mendukung percepatan wisata halal (Pratiwi, et al, 2017). Selain itu, Kota Bandung juga mengalami peningkatan jumlah wisatawan selama kurun 4 tahun terakhir.

Pariwisata di suatu daerah bergantung potensi dan sumber daya pariwisata itu sendiri. Sumber daya dalam konteks pariwisata diartikan sebagai segala sesuatu yang mempunyai potensi untuk dikembangkan guna mendukung pariwisata, baik secara langsung maupun tidak langsung, misalnya sumber daya alam dan sumber daya budaya (Pitana \& Diarta, 2009). Kota Bandung memiliki banyak peluang yang

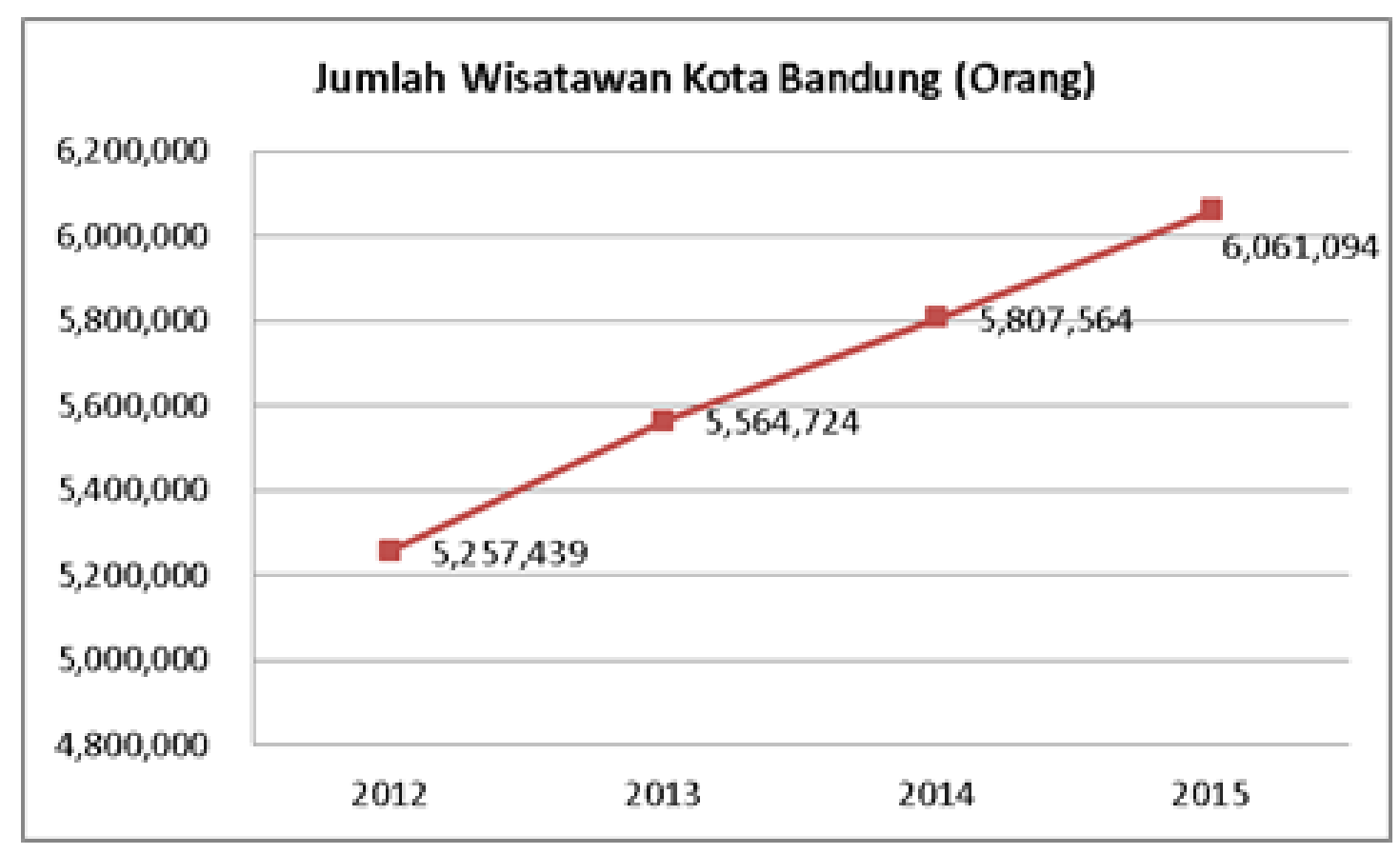

Sumber: diolah dari Rekapitulasi Data Kunjungan Wisatawan Kota Bandung oleh Dinas Kebudayaan dan Pariwisata Kota Bandung, 2015

Gambar 1 Jumlah Kunjungan Wisatawan ke Kota Bandung 
dapat dimanfaatkan pada pengembangan wisata halal, seperti mayoritas penduduk beragama Islam, akses ke berbagai destinasi pariwisata yang semakin berkembang, dan daya tarik wisata yang meningkat. Wisata halal mampu berperan dalam mendorong pertumbuhan ekonomi di Kota Bandung.

Di balik peluang yang dimiliki oleh Kota Bandung, terdapat masalah yang menjadi hambatan dalam mempersiapkan Kota Bandung sebagai destinasi wisata halal. Awareness (kepedulian) dan perhatian para pemangku kepentingan (stakeholders) untuk mengembangkan wisata halal di kota ini masih belum terbangun. Hal tersebut dapat dilihat dari besarnya potensi pariwisata halal di Kota Bandung. Akan tetapi, pengetahuan dan wawasan akan konsep maupun prinsip pariwisata ini belum begitu menggaung, baik di kalangan pemerintah setempat maupun pelaku industrinya. Dinas Kebudayaan dan Pariwisata Kota Bandung saat ini belum memiliki konsep terkait pengembangan wisata halal dan belum ada kebijakan atau regulasi khusus mengenai pengembangan wisata halal. Hingga kini penanganan wisata halal masih berada pada tingkat provinsi yaitu oleh Dinas Pariwisata dan Kebudayaan Provinsi Jawa Barat.

Hambatan lainnya adalah produk wisata terutama kuliner di Kota Bandung cenderung menjadi halal dengan sendirinya atau halal 'by default' karena penduduknya yang mayoritas adalah muslim. Akibatnya timbul perasaan aman dan sikap kurang kritis terhadap aspek halal dan thayyib pada produk yang dikonsumsinya. Berdasarkan regulasi, diperlukan sertifikat halal yang dikeluarkan oleh MUI untuk menjamin kehalalan dan thayyibnya suatu produk. Halal sendiri telah menjadi konsep yang universal, konsep ini tidak hanya terbatas pada pembantaian hewan, namun juga mencakup produk dan layanan dengan kualitas terbaik, yang memenuhi peningkatan kesadaran dan kebutuhan konsumen masing-masing di pasar global (Hasan, 2016).

Chanin, et al (2015) menjelaskan bahwa industri pariwisata merupakan industri yang besar dan dipandang sebagai sektor yang mempercepat pertumbuhan ekonomi. Dampak dari kesuksesan industri pariwisata adalah mampu meningkatkan kunjungan turis, pendapatan pemerintah, dan dapat bermanfaat bagi masyarakat setempat sebagai ladang pekerjaan. Hal ini menyebabkan persaingan yang tinggi antar destinasi wisata untuk menarik wisatawan. Tentunya, untuk menarik wisatawan diperlukan strategi pengembangan seperti membuat segmen pasar yang baru.

Dalam kasus ini, Kota Bandung menarik pangsa pasar baru yakni wisatawan muslim. Sebelum menarik pangsa pasar wisatawan muslim ini, Kota Bandung harus mempersiapkan diri terlebih dahulu untuk menjadi destinasi wisata halal yang unggul.

Konsep halal, artinya diperbolehkan dalam Bahasa Arab, tidak hanya diaplikasikan pada makanan, tapi juga termasuk pariwisata dalam kasus ini. Artinya, program pariwisata yang mengusung konsep halal harus menawarkan konsep paket wisata dan destinasi yang sangat khusus dirancang untuk memenuhi kebutuhan wisatawan muslim (Chanin, et al, 2015). Dalam mempersiapkan Kota Bandung sebagai destinasi wisata halal, konsep dan prospek wisata halal sendiri perlu dikomunikasikan dengan jelas kepada para pemangku kepentingan yang berkaitan. Salah satu bentuk permasalahan awareness lain yang ditemui di lapangan adalah perbedaan persepsi soal standardisasi hotel yang ada pada konsep wisata halal. Terdapat pandangan yang menyatakan bahwa persyaratan sertifikasi halal yang diberlakukan dalam wisata halal tidak sesuai dengan karakteristik industri perhotelan. Selain itu, bagi pelaku industri hotel yang belum sadar (aware) dan tidak terlalu mengenal konsep halal atau konsep ramah muslim (muslim friendly) maka mereka akan mengelami kesulitan dalam prosesnya. Ketika wisata halal ini ternyata tidak dapat memberikan keuntungan bagi pelaku bisnis, maka bukan tidak mungkin bisnis mereka akan berhenti.

Masalah wisata halal di atas perlu ditangani secepatnya untuk mempersiapkan Kota Bandung menjadi destinasi wisata halal. Salah satu caranya adalah dengan membangun awareness para pemangku kepentingan, pelaku industri, dan juga masyarakatnya melalui sebuah strategi komunikasi. Kennedy dan Soemanagara mengatakan bahwa strategi komunikasi memiliki tiga sasaran perubahan yang terdiri dari mengubah kesadaran, perhatian, dan kesetiaan (Bungin, 2015). Menurut Priyatna dan Ardianto tujuan strategi komunikasi sebagai cara untuk membangun kesadaran harus memperhatikan hal-hal seperti pemahaman terhadap proses komunikasi, kejelasan pesan, daya persuasi, 
dan juga kelengkapan pesan (Bungin, 2015).

Jones (2009) menjelaskan bahwa strategi komunikasi bukanlah proses yang pasif, yang berorientasi pada sumber yang bertujuan untuk menyampaikan pesan yang paling tepat untuk publik atau untuk menginformasikan kepada masyarakat, tetapi proses komunikasi yang aktif dan melibatkan publik. Strategi komunikasi bertujuan meyakinkan opini publik juga membentuk sikap dan perilaku masyarakat (Seyitoglu \& Yuzbasioglu, 2015). Dalam hal ini, komunikasi menjadi sangat penting untuk memulai jalannya suatu program atau kegiatan. Ada elemen-elemen penting komunikasi yang harus diperhatikan saat merencanakan sebuah strategi komunikasi, yakni komunikator (sumber); pesan; media (sistem); dan penyampai; tujuan atau sasaran (Bungin, 2015).

Strategi komunikasi merupakan rangkaian aktivitas berkelanjutan dan koheren yang sistematis, dilakukan secara taktis, yang memungkinkan pemahaman terhadap khalayak sasaran, mengidentifikasi saluran yang efektif, dan mengembangkan dan mempromosikan gagasan dan opini melalui saluran tersebut dalam rangka mempromosikan dan mempertahankan jenis perilaku tertentu (Tatham, 2008). Definisi ini mengindikasikan bahwa strategi komunikasi digunakan sebagai alat untuk mengubah perilaku dan diperlukan perencanaan dalam mencapai tujuan strategi komunikasi tersebut.

Dalam rangka membangun komunikasi yang efektif diperlukan tindakan yang terorganisasi dalam menyampaikan pesan. Salah satu cara untuk mencapai komunikasi yang efektif adalah dengan menggunakan model AIDA pada strategi komunikasi yang dibuat, yakni attention, interest, desire, action. Model AIDA memiliki tahapan yang ditunjukkan oleh tabel 1 .

Meskipun pada praktiknya sektor swasta yang memberikan layanan langsung kepada wisatawan, pemerintah setempat bersama penyedia produk dan layanan pariwisata dapat bekerja sama dalam sejumlah bidang guna membangun awareness dan mendukung Kota Bandung sebagai destinasi wisata halal. Menurut Hasan (2016), pemerintahan merupakan organisasi yang memiliki hak tertinggi untuk melaksanakan kewenangan. Tugas pokok pemerintahan adalah menciptakan kondisi masyarakat yang kondusif dan stabil dalam hal keamanan, ketertiban, keadilan, kesejahteraan sosial, ekonomi, pekerjaan umum, serta pemeliharaan sumber daya alam dan lingkungan hidup (Senova, 2016). Sejatinya, Pemerintah adalah penanggung jawab dan pemilik wewenang dalam pengembangan wisata halal ini. Pengembangan wisata halal perlu dukungan dalam berbagai cara termasuk meningkatkan kesadaran di antara penyedia jasa dan produk pariwisata, mendukung dalam mengembangkan dan melakukan sertifikasi produk dan jasa wisata halal, serta terlibat dalam pemasaran. Kewajiban tersebut perlu dikomunikasikan kepada pemerintah terkait

Tabel 1 Model AIDA

\begin{tabular}{ll}
\hline Tahap & Sasaran \\
\hline Attention (perhatian) & Menunjukkan manfaat nyata atau nilai \\
& tertentu guna mendapatkan perhatian sasaran \\
& komunikasi \\
Interest (minat) & Membangun perhatian sasaran melalui \\
& penjelasan lanjutan tentang manfaat tersebut \\
& secara logik dan emosional \\
& Membangun keinginan dengan memberikan \\
Desire (keinginan) & perincian pendukung tambahan dan menjawab \\
& pertanyaan potensial \\
& Memotivasi untuk melakukan langkah \\
Action (tindakan) & berikutnya melalui closing dengan kegiatan \\
& yang menarik untuk melakukan tindakan \\
\hline
\end{tabular}

Sumber: Diolah dari Bungin, 2015 
dan para pelaku industri.

Penelitian ini menggunakan teori Konstruksi Sosial Atas Realitas. Teori ini diperkenalkan oleh Peter L. Berger dan Thomas Luckmann. Konstruksi Sosial Atas Realitas menggambarkan proses sosial melalui tindakan dan interaksinya, bahwa individu menciptakan secara terus menerus suatu realitas yang dimiliki dan dialami bersama secara subjektif (Bungin, 2011).

Berger dan Luckmann mendasari pemikiran teori konstruksi sosial atas realitas pada aliran fenomenologis, yakni proses sosial di antara anggota masyarakat berlangsung secara alami. Burger dan Luckmann menjelaskan bahwa isi pesan konstruksi sosial terhadap realitas berawal dari pemimpin kepada bawahan, begitu juga yang terjadi pada guru kepada murid, orang tua kepada anak, dan lainnya. Dengan demikian, dapat disimpulkan bahwa konstruksi sosial terhadap realitas dipengaruhi oleh pihak penguasa yang melakukan pesan konstruksi sosial terhadap realitas, sementara orang umum merupakan pihak yang dikonstruksi (Bungin, 2015).

Konstruksi sosial atas realita terjadi melalui tiga tahapan, yakni: (1) eksternalisasi; (2) objektivasi; (3) internalisasi. Eksternalisasi merupakan penyesuaian diri dengan dunia sosio-kultural sebagai produk manusia. Tahap eksternalisasi terjadi ketika produk sosial tercipta dalam masyarakat, kemudian individu mengeksternalisasikan (penyesuaian diri) ke dalam dunia sosiokulturalnya sebagai bagian dari produk manusia (Bungin, 2011).

Selanjutnya adalah objektivasi. Tahap ini berawal pada pemahaman atau penafsiran langsung dari suatu peristiwa objektif sebagai pengungkapan suatu makna. Pada tahap objektivasi, sebuah produk sosial berada pada proses intitusionalisasi (pelembagaan). Lembaga muncul sebagai produk sosial yang tidak direncanakan. Dari waktu ke waktu, orangorang mulai melegalkan praktik tersebut karena terus berkembang dan berubah. Kebiasaan orang yang terus-menerus diulangi kemudian menjadi dibakukan. Dari situlah lembaga tumbuh (Berger \& Luckmann, 1990).

Tahapan terakhir adalah internalisasi. Internalisasi merupakan pemahaman atau penafsiran yang langsung dari suatu peristiwa objektif sebagai pengungkapan suatu makna. Setiap individu tidak hanya memahami definisi pihak lain tentang kenyataan sosial yang dialaminya bersama, namun juga mendefinisikan kenyataan-kenyataan itu secara timbal balik. Sehingga individu terlibat dan berpartisipasi dalam keberadaan pihak lain (Bungin, 2011).

Dalam penelitian ini peneliti berusaha mengangkat masalah, bagaimana mengatasi kurangnya perhatian dan kepedulian dari para pemangku kepentingan untuk membangun wisata halal di Kota Bandung agar wisata tersebut berkembang lebih pesat dan terukur. Tujuan dari penelitian ini adalah untuk mengetahui alasan belum terbentuknya awareness wisata halal di Kota Bandung dan untuk memetakan strategi komunikasi dalam membangun perhatian dan kepedulian terhadap wisata halal di Kota Bandung.

\section{METODE PENELITIAN}

Penelitian ini menggunakan metode kualitatif dengan jenis penelitian studi kasus. Dalam riset kualitatif, peneliti turut aktif dalam menentukan jenis data yang diinginkan. Periset harus terjun langsung di lapangan, sehingga hasilnya lebih kasuistik bukan untuk digeneralisasikan (Kriyantono, 2006). Pada penelitian studi kasus, peneliti mengidentifikasi dan menganalisis suatu isu atau problem yang spesifik (Cresswell, 2014). Studi kasus yang digunakan adalah studi kasus instrumental tunggal, yang mana menurut Stake (dalam Cresswell, 2014) penelitian studi kasus instrumental tunggal berfokus pada satu isu dan selanjutnya peneliti menentukan satu kasus terbatas untuk dikaji.

Pengumpulan data dalam penelitian studi kasus dilakukan secara detail dan mendalam yang melibatkan beragam sumber informasi atau sumber informasi majemuk (wawancara, pengamatan, dokumen, dan sebagainya). Data primer dalam penelitian ini didapat melalui wawancara mendalam dan observasi.

Wawancara dilakukan kepada enam orang informan penelitian yang terdiri dari 2 key informan yakni Ibu Lia Amalia dan Bapak Puspo dari Dinas Pariwisata dan Kebudayaan Provinsi Jawa Barat, serta 4 orang informan pendukung lainnya yakni, Bapak Prof. Dr. K.H Miftah Faridl sebagai ketua MUI Kota Bandung; Bapak Wisnu Rahtomo Pratomo sebagai perwakilan Enhaii Halal Tourism Center dan dosen senior 
Sekolah Tinggi Pariwisata (STP) Bandung; Bapak Nashir Budiman sebagai pengamat wisata halal dan anggota Dewan Pembina Pusat Halal Salman ITB; dan Bapak Ahmad Gemma Nurrahman sebagai General Manager salah satu hotel yang memberlakukan konsep syariah di Kota Bandung. Pada wawancara ini, informan diberikan sejumlah pertanyaan yang mengacu pada tujuan penelitian dan apabila pertanyaan yang diajukan masih belum memenuhi kriteria yang dibutuhkan, maka peneliti mengembangkan pertanyaan lain guna mendapatkan data yang sesuai dan mendalam.

Sedangkan observasi dilakukan dengan cara mendatangi event yang berhubungan dengan pengembangan produk halal di Kota Bandung. Observasi yang dilakukan bersifat non partisipan, yang artinya peneliti hanya berperan sebagai pengamat tanpa terjun melakukan kegiatan yang dilakukan oleh pihak yang diteliti.

Selain itu, peneliti juga menggunakan pencarian informasi melalui buku, jurnal, dokumen resmi terkait, website Dinas Pariwisata dan Kebudayaan Provinsi Jawa Barat, media sosial, seminar terkait wisata halal, dan berita online yang selanjutnya dijadikan sebagai data sekunder.

\section{HASIL DAN PEMBAHASAN}

Tujuan Kementerian Pariwisata membuat wisata halal di Indonesia adalah untuk memperkaya varian industri pariwisata dengan menebarkan daya tarik konsep halal, sambil menampilkannya secara 'inklusif'. Tujuan lainnya yaitu untuk menciptakan suatu tren baru dalam kehidupan dan masyarakat yang dapat diterima oleh semua. Konsep wisata halal tidak terbatas pada satu golongan saja, melainkan mencakup semua ras, etnis dan agama. Esensi khusus dari wisata halal ini adalah untuk menghilangkan unsur-unsur berbahaya dan merusak pada produk atau jasa pariwisata.

Konstruksi sosial terhadap realitas dipengaruhi oleh pihak penguasa yang melakukan pesan konstruksi sosial terhadap realitas, sementara orang umum merupakan pihak yang dikonstruksi (Bungin, 2015). Dalam penelitian ini, perencanaan strategi komunikasi dalam membangun awareness Kota Bandung sebagai destinasi wisata halal merupakan hasil ciptaan dari Dinas Pariwisata dan Kebudayaan
Provinsi Jawa Barat bersama dengan instansi lain yang terlibat. Pemerintah dan instansi lain yang terlibat menjadi pihak penguasa yang melakukan konstruksi sosial, sedangkan masyarakat dan pihak lain yang terlibat menjadi bagian yang dikonstruksi. Tidak hanya itu, wisata halal sendiri merupakan sebuah penciptaan dari hasil realitas. Realitas yang dimaksud adalah fenomena wisatawan muslim yang melakukan perjalanan ke destinasi wisata dan membutuhkan fasilitas wisata yang sesuai dengan aturan-aturan Islam.

Pada tahap objektivasi dalam teori konstruksi sosial atas realitas, terdapat hal penting yakni pembuatan signifikasi (pembuatan tanda-tanda oleh manusia). Bahasa merupakan salah satu alat simbolis untuk melakukan signifikasi. Bahasa digunakan untuk menyignifikasi makna-makna yang dipahami sebagai pengetahuan yang relevan dengan masyarakat (Bungin, 2015). Dalam konsep wisata halal, terdapat pengetahuan baru yang perlu diketahui oleh pelaku industri dan juga masyarakat. Dari mulai definisi dan prinsip wisata halal sendiri, kebijakan wisata halal, hingga penerapannya. Semuanya disampaikan melalui berbagai macam kegiatan komunikasi.

Teori konstruksi sosial atas realitas menjelaskan bahwa individu sebagai anggota masyarakat berusaha mengonstruksi realitas melalui proses sosial, yaitu interaksi yang dilakukan individu dengan orang lain secara terus menerus melalui tiga tahapan (eksternalisasi, objektivasi, dan internalisasi). Disparbud Jawa Barat melihat banyaknya jumlah penduduk muslim serta fasilitas yang mendukung wisata halal di Jawa Barat, khususnya Kota Bandung sebagai suatu hal yang memiliki potensi untuk dikembangkan. Maka, Disparbud Jawa Barat pun berusaha mengonstruksi fenomena tersebut menjadi sebuah realitas baru yang disebut wisata halal. Wisata halal ini kemudian disebarkan melalui interaksi dengan masyarakat secara terus menerus.

Wisata halal merupakan program dari Kementerian Pariwisata. Industri wisata halal ditinjau berdasarkan industri yang berkaitan dengan halal. Misalnya, tour and travel, food and beverages. Kota Bandung telah memiliki atraksi dan objek wisata yang beragam. Meski begitu, tidak semua atraksi dan objek wisata tersebut dapat digolongkan ke dalam industri wisata halal. Apabila mengacu pada definisi 
wisata halal dijelaskan bahwa objek atau aksi wisata yang diperbolehkan untuk digunakan atau dilibatkan dalam industri wisata halal harus mengacu pada ajaran Islam (Battour \& Ismail, 2015). Pada kasus ini, maka pengembangan wisata halal di Kota Bandung harus mempertimbangkan banyak aspek dari mulai sarana dan akomodasi halal, hingga kesiapan sumber daya manusia untuk mendukung wisata halal itu sendiri.

Sebenarnya, dalam buku panduan 'Indonesia Guide for Muslim Visitor' yang dibuat atas kerjasama Kementerian Pariwisata dan HalalTrip, terdapat petunjuk-petunjuk bagi wisatawan muslim yang ingin berwisata halal di Indonesia. Buku panduan tersebut berisikan panduan wisata halal di beberapa kota di Indonesia, termasuk Kota Bandung. Panduan dalam buku dibagi menjadi beberapa kategori seperti: apa saja yang dapat dilakukan (things to do); lokasi wisata kuliner (dining) yang setiap tempat tersebut diberikan keterangan apakah tempat tersebut halal, halal-friendly atau porkfree; fasilitas beribadah (praying facilities); dan akomodasi (accomodation).

Program pariwisata yang mengusung konsep halal harus menawarkan konsep paket wisata dan destinasi yang sangat khusus dirancang untuk memenuhi kebutuhan wisatawan muslim (Chanin, et al, 2015). Dalam buku panduan 'Wonderful Indonesia: A Muslim Travel Guide', telah dipetakan beberapa tempat yang dijadikan rekomendasi bagi para wisatawan muslim. Misalnya, dalam buku tersebut diberi arahan apabila wisatawan ingin menginap di hotel syariah atau hotel yang memiliki konsep moslem friendly, wisatawan dapat mengunjungi Noor Hotel, GH Universal,

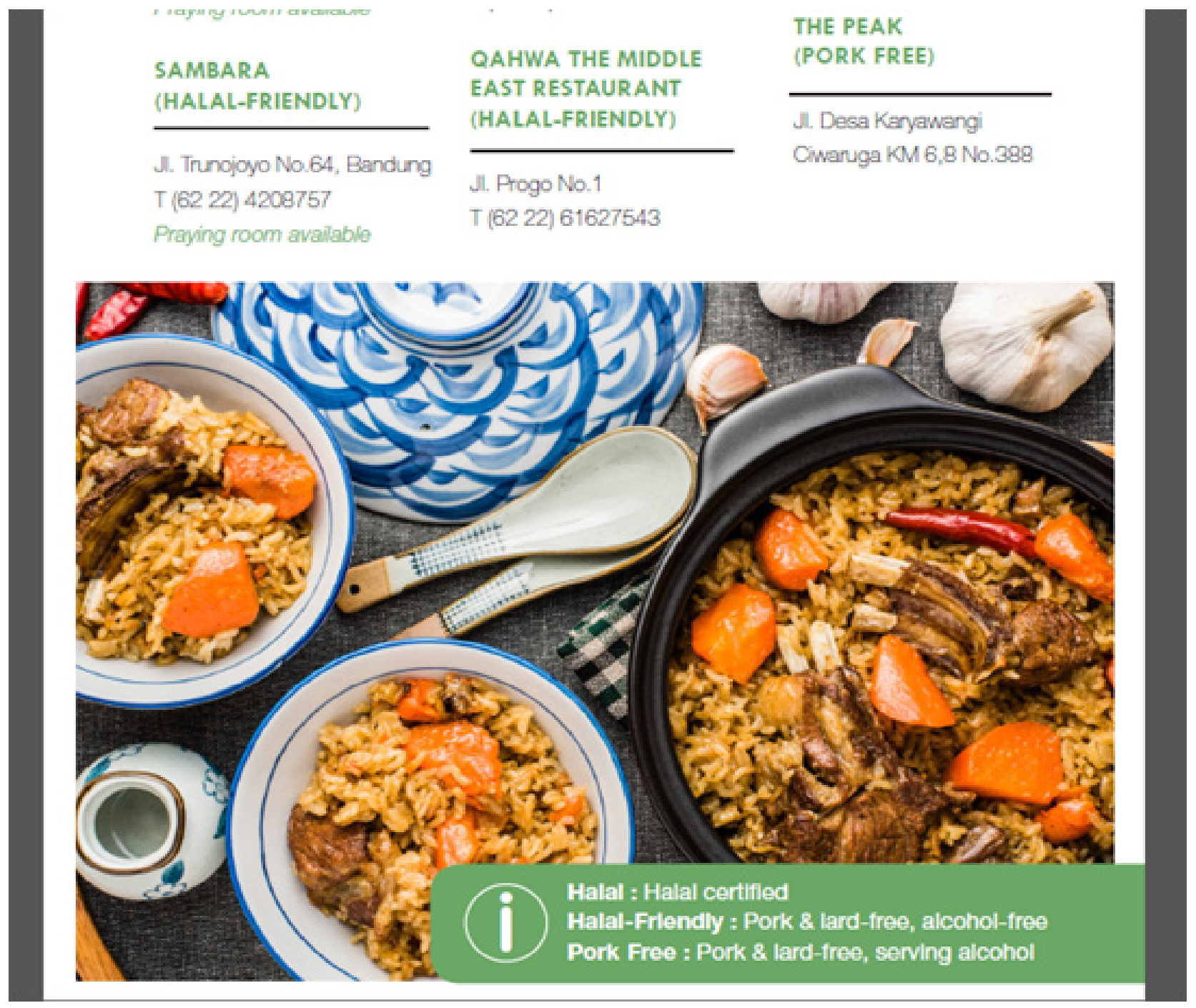

Sumber: Buku Panduan Indonesia Guide for Muslim Visitor, 2016

Gambar 2 Informasi Restoran di Kota Bandung yang Disertai Keterangan 
Orange's Home Syariah, dan sebagainya. Buku panduan tersebut juga memberikan rekomendasi jenis wisata yang menjadi keunggulan di Kota Bandung selama ini, yakni kuliner dan pusat perbelanjaan. Buku tersebut juga memberikan rekomendasi kuliner khas Kota Bandung yang dapat dinikmati wisatawan muslim seperti cilok, nasi timbel, batagor, dan mie kocok.

Namun, sayangnya peta wisatahalal tersebut baru dicetuskan oleh Kementerian Pariwisata saja. Dinas Kebudayaan dan Pariwisata Kota Bandung belum memiliki konsep wisata halal dan juga peta wisata halalnya sendiri, yang tentu saja dapat memberikan gambaran lebih banyak mengenai kondisi Kota Bandung sebagai destinasi wisata halal.

Sumber daya dalam konteks pariwisata diartikan sebagai segala sesuatu yang mempunyai potensi untuk dikembangkan guna mendukung pariwisata, baik secara langsung maupun tidak langsung, misalnya sumber daya alam dan sumber daya budaya (Pitana \& Diarta, 2009). Ketersediaan infrastruktur, produk, serta layanan wisata di Kota Bandung sudah mampu mendukung pengembangan wisata halal. Berdasarkan hasil penelitian oleh Enhaii Halal Tourism Center, kondisi Kota Bandung saat ini sudah memiliki produk serta layanan yang cukup lengkap dan variatif untuk memenuhi kebutuhan wisatawan muslim. Lalu, ditambah dengan kondisi Kota Bandung sebagai kota dengan mayoritas penduduk muslim, unsur masyarakat sudah cukup potensial memenuhi prakondisi pariwisata halal. Beberapa lembaga pendidikan seperti Institut Teknologi Bandung (ITB) dan Sekolah Tinggi Pariwisata (STP) Bandung pun sudah melaksanakan perannya dalam mengembangkan wisata halal.

Pengembangan wisata halal di Indonesia, khususnya Kota Bandung dapat dikatakan terlambat apabila dibandingkan dengan negara lain. Keterlambatan ini karena masih minimnya perhatian pemerintah dalam menangkap peluang industri wisata halal. Berdasarkan hasil wawancara, ada tiga hal yang membantu dalam mengupayakan pengembangan wisata halal. Pertama, ketersediaan industri pendukung wisata halal. Kedua, kemauan kabupaten atau kota untuk mengembangkan wisata jenis ini. Ketiga, adanya asosiasi yang menangani wisata halal.

Berdasarkan hasil penelitian, diketahui bahwa pengembangan wisata halal di Kota
Bandung dilakukan dengan cara pentahelix. Strategi pentahelix merupakan strategi dalam mendukung pariwisata oleh akademisi (academics), pemilik bisnis (business), komunitas (community), pemerintah (government), dan media. Dinas Pariwisata dan Kebudayaan Provinsi Jawa Barat merupakan fasilitator dan pemegang kebijakan, pada praktiknya bersama-sama dengan lembaga lain mengelola persiapan serta pengembangan wisata halal di Kota Bandung.

Dalam rangka mendukung persiapan dan pengembangan wisata halal, diperlukan suatu strategi komunikasi untuk meningkatkan awareness para pemangku kepentingan. Strategi komunikasi menurut Jones (2009) merupakan sebuah proses komunikasi yang aktif dan melibatkan publik. Strategi komunikasi komunikasi bertujuan meyakinkan opini publik juga membentuk sikap dan perilaku masyarakat (Seyitoglu\&Yuzbasioglu,2015).Padapenelitian ini, strategi komunikasi digunakan oleh Dinas Pariwisata dan Kebudayaan Provinsi Jawa Barat, Enhaii Halal Tourism Center, Salman Halal Center, dan MUI Kota Bandung untuk mengomunikasikan prinsip-prinsip wisata halal kepada para pemangku kepentingan, dengan tujuan terbentuknya kesadaran bersama untuk mendukung program wisata halal ini.

Menurut Priyatna dan Ardianto (2009) tujuan strategi komunikasi sebagai cara untuk membangun kesadaran harus memperhatikan hal-hal seperti pemahaman terhadap proses komunikasi, kejelasan pesan, daya persuasi, dan juga kelengkapan pesan (Bungin, 2015). Upaya komunikasi yang dilakukan oleh Dinas Pariwisata dan Kebudayaan Provinsi Jawa Barat adalah dengan menyelenggarakan sosialisasi bagi para pemangku kepentingan. Apabila dikaji melalui model AIDA, upaya komunikasi ini berada pada tahap attention. Karena sosialisasi diselenggarakan guna memaparkan konsep wisata halal itu sendiri beserta prospeknya di masa depan.

Dinas Pariwisata dan Kebudayaan Provinsi Jawa Barat mengerahkan tim yang dinilai tepat untuk menangani sosialisasi wisata halal, yang terdiri dari lintas bidang seperti bidang pemasaran, bidang destinasi, dan juga bidang industri pariwisata. Selain tim dari Disparbud Provinsi Jawa Barat, disertakan pula lembaga lain yang lebih ahli guna memaksimalkan sosialisasi, seperti SKPD lain yang terkait dan 
MUI.

Media yang digunakan oleh Dinas Pariwisata dan Kebudayaan Provinsi Jawa Barat untuk menyampaikan informasi wisata halal adalah melalui seminar, publikasi melalui website dan media sosial, serta rencana selanjutnya adalah melalui pelatihan. Terlepas dari upaya yang dilakukan oleh Dinas Pariwisata dan Kebudayaan Provinsi Jawa Barat, gerakan untuk mendukung konsep halal di Kota Bandung mulai terlihat. Dinas Perdagangan dan Perindustrian Kota Bandung menyelenggarakan Bandung Halal Fest pada tanggal 28 - 30 April 2017, yang berlokasi di Graha Manggala Siliwangi, Kota Bandung. Bandung Halal Fest merupakan pameran produk halal yang berasal dari Kota Bandung. Acara ini diisi oleh 72 UKM yang sudah memiliki sertifikat halal MUI dan masih berlaku sertifikatnya.

Tujuan dari diselenggarakannya Bandung Halal Fest 2017 adalah memberikan fasilitasi bagi UKM yang ingin mendaftarkan produknya dan mendapatkan sertifikat halal MUI, sekaligus menjadi ajang bagi UKM yang sudah memiliki sertifikat MUI untuk memamerkan produknya di acara tersebut. Dinas Perdagangan dan Perindustrian juga ingin mendorong Kota Bandung sebagai 'Bandung Kota Kuliner, Bandung Kota Halal'. Selain itu, Disdagin berharap melalui acara ini, masyarakat memiliki wawasan dan kepedulian terhadap produk-produk lokal khususnya produk dengan sertifikasi halal (Arnanda, 2017). Dalam model komunikasi AIDA, Bandung Halal Fest berada pada tahap yang lebih lanjut, yakni tahap action. Dengan diselenggarakannya Bandung Halal Fest, para pelaku industri tidak hanya diberikan informasi mengenai manfaat atau nilai dari produk halal saja, namun juga sekaligus memberikan fasilitas bagi mereka untuk melakukan pendaftaran sertifikasi halal yang diberikan oleh MUI.

Strategi komunikasi wisata halal ini mengacu pada strategi penta helix di mana

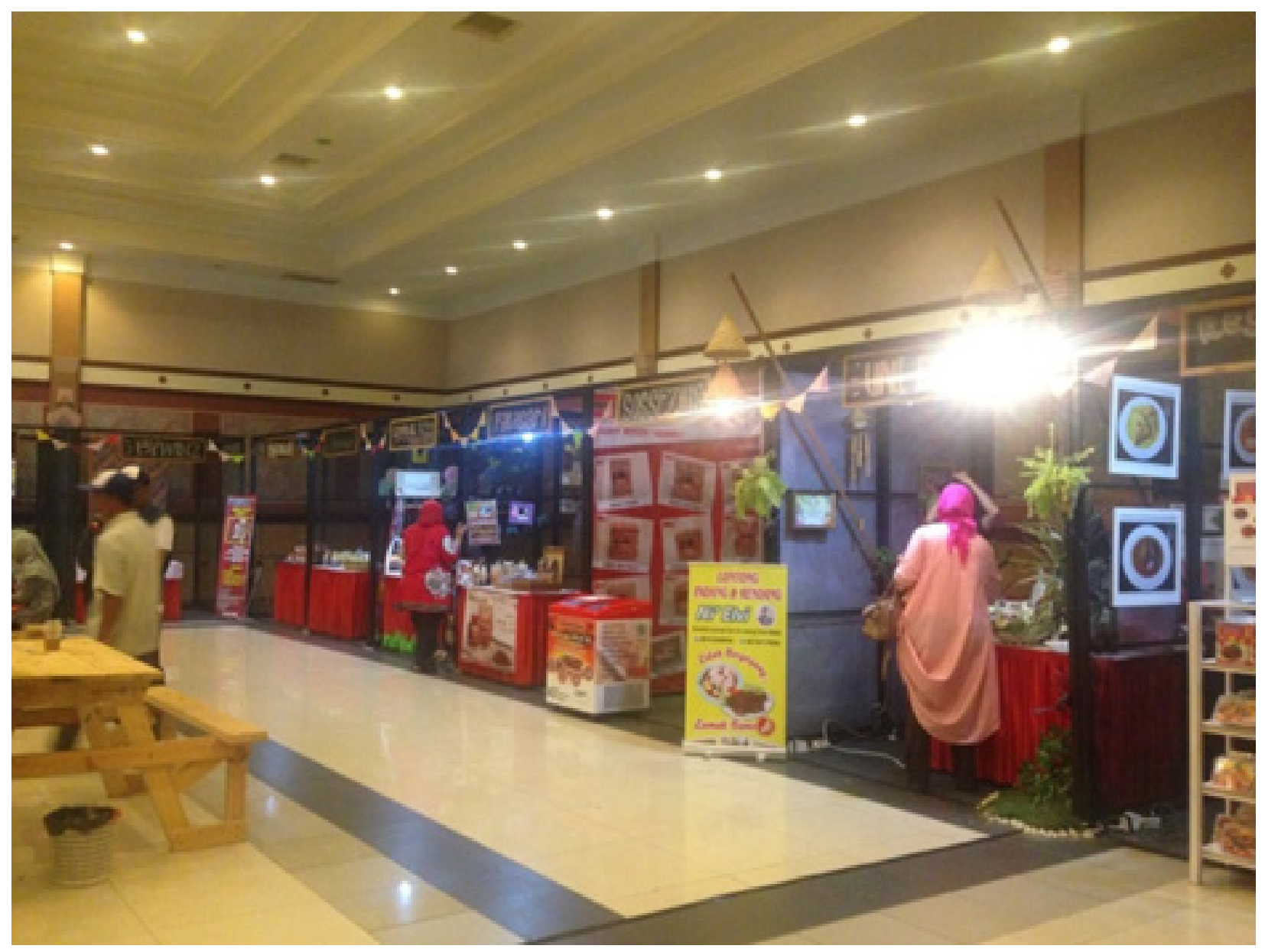

Sumber: Dokumentasi peneliti, 2017

Gambar 3 Suasana Bandung Halal Fest 2017 
akademisi pun merupakan bagian dari pihak yang melakukan penyebaran pesan. Terdapat Enhaii Halal Tourism Center (EHTC) yang berperan melakukan riset serta sosialisasi. Sosialisasi yang dilakukan EHTC bertujuan untuk membangun kesadaran (building awareness) dan advokasi. EHTC pada Desember 2016 lalu telah menyelenggarakan Diseminasi Penelitian terkait wisata halal dengan mengundang stakeholders dan media.

Diseminasi penelitian tersebut
menghasilkan beberapa point penting mengenai ekosistem wisata halal di Kota Bandung yang digambarkan melalui: (1) potensi produk dan pelayanan wisata halal di Kota Bandung; (2) dukungan pemerintah terhadap pariwisata halal di Kota Bandung; (3) potensi sumber daya manusia bagi pengembangan pariwisata halal di Kota Bandung; (4) infrastruktur dalam pengembangan wisata halal di Kota Bandung.

Selain menggelar diseminasi penelitian, EHTC juga memiliki website tersendiri dan telah menyelenggarakan sosialisasi kepada para pedagang di kantin STP Bandung mengenai pentingnya penggunaan bahan dan produk halal. Ke depannya, EHTC berencana untuk menyelenggarakan sosialisasi serupa kepada beberapa UKM yang berlokasi di sekitar Sekolah Tinggi Pariwisata (STP) Bandung. Hal tersebut dilakukan karena EHTC memiliki misi untuk membangun kesadaran para pedagang kecil dan UKM agar lebih memperhatikan kehalalan suatu produk atau bahan pangan yang digunakan. EHTC memiliki tim ahli yang disebut expert pool yang dikerahkan pada saat sosialisasi. EHTC juga memiliki website yang di dalamnya membahas serta mempublikasikan berbagai macam aktivitas yang telah mereka lakukan.

Upaya building awareness yang dilakukan oleh EHTC diselenggarakan melalui pelatihan, seminar, dan rapat yang disesuaikan dengan sasaran komunikasinya. Tidak hanya itu, EHTC pun bekerja sama dengan media online untuk mempublikasikan hasil penelitiannya. Sehingga aktivitas EHTC ini dapat diketahui oleh masyarakat dan visi misi EHTC dapat tercapai.

Selain EHTC, terdapat juga upaya komunikasi yang dilakukan Salman Halal Center ITB untuk mendorong awareness wisata halal di Kota Bandung. Kementerian Pariwisata menunjuk Salman Halal Center sebagai pusat halal di Kota Bandung. Dalam melakukan perannya sebagai pusat halal, Salman Halal Center melakukan upayanya melalui pendekatan sosiopreneurship. Hal ini dilakukan karena mereka melihat aspek halal sebagai aspek sosial, sekaligus digabungkan dengan aspek entrepreneurship.

Kegiatan yang dilakukan Salman Halal Center cenderung menyasar masyarakat karena masyarakat juga perlu dibangun kesadarannya supaya siap dengan wisata halal ini. Masyarakat menjadi target penting karena ditakutkan ketika industri, hotel, UKM harus mendukung wisata halal namun di lain pihak masyarakatnya belum sadar atau tahu manfaatnya maka program wisata halal di Kota Bandung tidak akan mudah untuk diselenggarakan. Salman Halal Center juga mengaku memiliki akses yang luas karena selama ini Lembaga Salman selalu berhubungan langsung dengan masyarakat. Cara yang dilakukan untuk dekat dengan masyarakat juga bermacam-macam, seperti ceramah, dakwah, jaringan alumni, dan kepopuleran Lembaga Salman sendiri pun menjadi keuntungan karena masyarakat yang sudah kenal dengan Lembaga Salman.

Sebagai pusat halal di Kota Bandung, Salman Halal Center menyelenggarakan seminar dengan mengundang praktisi atau ahli. Pembicara dalam acara seminar ini berasal dari berbagai kalangan yang berpengaruh pada perkembangan wisata halal, seperti menteri, gubernur, pelaku industri hotel syariah dan restoran halal, dan Dewan Syariah Nasional. Seminar membahas persiapan dan pengembangan pariwisata halal di Indonesia, hingga konsep pariwisata hotel syariah serta restoran halal.

Sedangkan untuk langkah selanjutnya, Salman Halal Center ingin mengadakan workshop terkait wisata halal yang mengundang seluruh stakeholders yang terlibat dan berpengaruh terhadap pengembangan wisata halal di Kota Bandung. Sama halnya dengan EHTC, Salman Halal Center pun menggunakan website dan bekerja sama dengan media untuk mempublikasikan kegiatan yang telah dan akan dilakukan.

Wisata halal tidak akan terbangun tanpa adanya dukungan dari Majelis Ulama Indonesia (MUI). MUI memiliki peran dan wewenang yang berbeda pada setiap wilayah. MUI Indonesia memiliki kewenangan untuk mengeluarkan sertifikat halal, MUI Jawa 
Barat memiliki kewenangan mengeluarkan sertifikat hanya pada sektor makanan saja, sedangkan MUI Kota Bandung tidak memiliki kewenangan mengeluarkan sertifikat halal dan hanya memberikan bimbingan serta fatwa. Oleh karena itu, MUI Kota Bandung berperan sebagai pendukung dalam program sosialisasi wisata halal yang diselenggarakan lembaga lain.

Baik MUI pusat maupun MUI Kota Bandung kerap diundang sebagai pembicara untuk menyampaikan pentingnya aspek halal. Pihak-pihak MUI Kota Bandung diundang untuk memberikan paparan terkait standardisasi produk dan konsep halal yang sesuai dengan syariat Islam. Selain itu, MUI juga melakukan sosialisasi melalui event yang berhubungan dengan pengembangan aspek halal di Kota Bandung.

Pada salah satu event yang bertajuk "Bandung Halal Fest 2017", MUI Kota Bandung memfasilitasi para penggiat usaha, terutama usaha kuliner untuk mendaftarkan produknya supaya mendapatkan sertifikasi halal MUI. Dalam acara tersebut, MUI Kota Bandung memberikan informasi melalui sebuah booth dan juga membagikan brosur-brosur yang berisi informasi tentang konsep halal menurut Islam dan juga syarat-syarat pendaftaran sertifikasi halal.

Pengembangan wisata halal di Kota Bandung dilakukan oleh berbagai lintas lembaga. Setiap lembaga memiliki kegiatan komunikasi masing-masing yang beragam serta sasaran komunikasi yang berbeda pula, namun memiliki tujuan yang sama yakni mempersiapkan wisata halal di Kota Bandung.

\section{SIMPULAN}

Wisata halal merupakan bagian dari industri pariwisata yang ditujukan untuk wisatawan muslim. Wisata halal mempertimbangkan hukum Islam dalam menentukan produk dan layanan wisata, seperti hotel, makanan, atraksi, dan perjalanan wisata itu sendiri. Hal yang harus dilengkapi dan tersedia dalam wisata halal dikenal dengan istilah faith based needs, yang terdiri dari: (1) makanan halal, (2) fasilitas beribadah yang layak, (3) pelayanan saat bulan Ramadhan, (4) toilet yang menyediakan air (water friendly washrooms), dan (5) fasilitas rekreasi yang memberikan privasi, dan (6) tidak ada aktivitas non halal.
Di Kota Bandung, produk dan layanan untuk mendukung wisata halal sudah tersedia. Sayangnya, jumlah dan varian produk yang tersedia tidak seimbang dengan jumlah produk yang sudah mendapatkan sertifikasi halal. Selain itu, dukungan berupa infrastruktur dan SDM belum terlihat, terutama belum adanya regulasi mengenai wisata halal serta Dinas Kebudayaan dan Pariwisata Kota Bandung yang belum memiliki konsep wisata halal itu sendiri.

Strategi pentahelix diimplementasikan pada pengembangan wisata halal di Kota Bandung. Pentahelix merupakan upaya pengembangan pariwisata di suatu daerah melalui berbagai macam pihak yakni akademisi, pemerintah, pelaku bisnis, komunitas, dan media. Sejauh ini pihak-pihak yang berperan mengembangkan wisata halal di Kota Bandung adalah Dinas Pariwisata dan Kebudayaan Provinsi Jawa Barat, STP Bandung, Salman Halal Center, dan MUI Kota Bandung. Pada umumnya, upaya komunikasi yang dilakukan oleh lembaga tersebut adalah melalui seminar dengan sasaran komunikasinya adalah $\neg$ stakeholders, UKM, dan SKPD terkait. Sehingga, upaya komunikasi yang dilakukan umumnya baru sampai tahap attention dan interest saja.

Rekomendasi peneliti adalah apabila Kota Bandung ingin menjadi destinasi wisata halal, maka sebaiknya edukasi dan program peningkatan kesadaran akan wisata halal ini perlu dilakukan untuk memaksimalkan potensi pasar dan sumber daya yang dimiliki. Model komunikasi AIDA dapat digunakan dalam melaksanakan strategi komunikasi yang diusung oleh Pemerintah Kota Bandung bersama lintas lembaga lainnya.

Dibutuhkan komitmen yang kuat dari Pemerintah (baik pada tingkatan pusat hingga tingkatan kota) untuk mendorong Kota Bandung sebagai destinasi wisata halal. Selain itu, komitmen juga dibutuhkan sebagai pendukung untuk membangun jaringan-jaringan industri wisata halal di Kota Bandung sekaligus memaksimalkan fasilitas dan pelayanan industri pariwisata di bidang wisata halal.

Tidak hanya Pemerintah, dibutuhkan komitmen juga dari para pelaku industri di Kota Bandung. Pelaku industri diharapkan memandang wisata halal untuk menjadi salah satu jenis pariwisata yang menjanjikan. Kedepannya, diharapkan wisata halal dapat menarik wisatawan Muslim dan non-Muslim. 
Dalam hal ini, Pemerintah dapat membangun kerja sama bersama Asosiasi Perusahaan Perjalanan Indonesia (ASITA), Perhimpunan Hotel dan Restoran Indonesia (PHRI), Badan Promosi Pariwisata Daerah (BPPD) Jawa Barat dan komunitas wisata lainnya yang ada di Kota Bandung.

\section{DAFTAR PUSTAKA}

Arnanda. (2017). Pemerintah kota bandung kenalkan masyarakat dengan kuliner halal di 'bandung halFest 2017'. Diakses dari http://gayahidup.dreamers.id/ article/62679/pemerintah-kota-bandungkenalkan-masyarakat-dengan-kulinerhalal-di-bandung-halFest-2017 pada 17 Oktober 2017.

Battour, M. \& Ismail, M. N. (2010). Toward a halal tourism market. Malaysia. http:// dx.doi.org/10.1002/jtr.824.

(2015). Halal tourism: concepts, practices, challenges, and future. Tourism Management Perspectives. $\quad \mathrm{http}: / / \mathrm{dx}$.doi.org/10.1016/j. tmp.2015.12.008.

Bungin, B. (2011). Sosiologi komunikasi: teori, paradigma dan teknologi komunikasi di masyarakat. Jakarta: Kencana Prenada Media.

(2015). Komunikasi pariwisata (tourism communication), pemasaran dan brand destinasi. Jakarta: Kencana Prenada Media.

Chanin, O., Sriprasert, P., Rahman, H. A., \& Don, M. S. (2015). Guidelines on halal tourism management in the andaman sea coast of thailand. Journal Of Economics, Business And Management. 3 (8). 791-794.

COMCEC. (2016). Muslim friendly tourism: understanding the demand and supply sided in the oic member countries. Turki.

Hasan, H. (2016). A study on awareness and perception towards halal foods among muslim students in kota kinabalu, sabah. Malaysia. 803-811.

Kementerian Pariwisata, HalalTrip. (2015). Indonesia guide for muslim visitors. Jakarta.

Pitana, I. G. \& Diarta, I. K. S. (2009). Pengantar ilmu pariwisata. Yogyakarta: Andi.

Pratiwi, S. R., Dida, S., \& Sjafirah, N. A. (2017). Strategi komunikasi dan tantangan wisata halal di kota bandung. Prosiding CCTC 2017: Penguatan Komunikasi Dalam Industri Pariwisata, Budaya, Dan Ekonomi Kreatif. Riau: Aspikom Wilayah Riau, 211219.

Seyitoglu, F. \& Yuzbasioglu, N. (2015). The role of strategic communication in hospitality industry. The Case Of Antalya. 2 (2), 16-35.

Senova, A. (2016). Literasi media sebagai strategi komunikasi tim sukses relawan pemenangan pemilihan. Jurnal Kajian Komunikasi. 4 (2), 142 - 153.

Tatham, S. (2008). Strategic communication: a primer. Shrivenham: Defence Academy of the United Kingdom.

Yuanita, P. (2016). Indonesia berpartisipasi dalam world halal tourism summit 2016. Diakses dari https://travel.dream.co.id/ news/indonesia-berpartisipasi-dalamworld-halal-tourism-summit-2016160812z.html. Pada 15 Oktober 2017. 